\title{
Indiologia brasileira: \\ literatura, fotografia e alteridade cultural na obra do austríaco Mario Baldi
}

\author{
[Brazilian Indiology: \\ literature, photography and cultural otherness in the work of the Austrian Mario Baldi] \\ http://dx.doi.org/10.1590/1982-8837182672103
}

\section{Marcos de Brum Lopes'}

\begin{abstract}
This article concerns photographic and narrative experiences of the Austrian photographer Mario Baldi, who worked among Brazilian Indians in the first half of the twentieth century. Baldi wrote a book about his relation with the Carajá and published it both in Brazil and Germany. This analysis aims to compare both versions of the book and consider the innovations and limits of the representations made by Baldi about the cultural otherness in Brazil. These representations, shared by both Brazilian and German authors, were influenced by an ethnological romantism, the so-called Brazilian Indiology in the 1940's and 1950's.
\end{abstract}

Keywords: narrative; photography; cultural otherness

Resumo: O artigo aborda as experiências fotografias e narrativas do fotojornalista austríaco Mario Baldi, que trabalhou entre os índios brasileiros na primeira metade do século XX. Baldi escreveu um livro sobre sua convivência com os Carajá e publicou tanto no Brasil quanto na Alemanha. O objetivo dessa análise é comparar as duas versões e abordar as inovações e limites das representações que Baldi faz da alteridade cultural brasileira, influenciadas por um romantismo etnológico compartilhado por alguns estudiosos brasileiros e alemães, denominado nos anos 1940 e 1950 de indiologia brasileira.

Palavras-chave: narrativa; fotografia; alteridade cultural

Em 1938, o fotógrafo austríaco Mario Baldi (1896-1957) foi enviado pelo jornal carioca A Noite para uma missão no interior do Brasil. Ele deveria acompanhar a jovem Doralice Avellar, cineasta pernambucana formada na Alemanha, e cobrir

\footnotetext{
${ }^{1}$ Museu Casa de Benjamin Constant - Arquivo Histórico, Rua Monte Alegre, 255, 20240-192, Rio de Janeiro, RJ, Brasil. Email: marcosfblopes@gmail.com. Pesquisa realizada com bolsa de doutorado do CNPq.
} 
fotograficamente o seu trabalho cinematográfico. Doralice voltou ao Brasil com o projeto de fazer um filme sobre a cultura do país, desde o nordeste até a Ilha do Bananal, onde viviam os índios Carajá. Infelizmente o filme até hoje não foi localizado, porém as fotografias feitas durante essa vivência entre os índios circularam na imprensa e na literatura entre 1938 e 1951. O objetivo desse artigo é analisar os significados e os limites desses discursos, verbais e visuais, que fizeram parte de um debate sobre alteridade cultural e constituição étnica do povo brasileiro, baseada no mito do cruzamento das raças indígenas, brancas e africanas.

\section{Um índio narrador}

Nos anos 1940, Mario Baldi começou a trabalhar em um livro que contaria suas aventuras entre os índios Carajá. Ele havia visitado esses índios em 1936 e 1938, tinha tomado notas das suas observações e feito muitas fotografias. Essas experiências foram narradas na imprensa brasileira e europeia, mas o fotojornalista austríaco desejava registrá-las numa contribuição literária. Os originais do livro foram feitos em alemão, sua língua nativa, mas a primeira versão foi publicada em português pela editora Melhoramentos, em 1950, com o título Uoni-Uoni conta sua história. Dois anos depois, leitores alemães puderam conhecer a narrativa de Baldi, publicada em Düsseldorf pela Bastion Verlag, com o título modificado: Uoni-Uoni ou os últimos índios da Água Grande (Uoni-Uoni oder die letzten Indianer am großen Wasser).

Como uma produção de um fotojornalista, Uoni-Uoni apresenta um conteúdo visual interessante, uma construção de palavras e imagens que se relacionam de forma específica, inovadora e provocativa. O livro é endereçado ao público jovem, ao qual era natural apresentar aspectos da formação nacional brasileira de forma leve e direta. A editora que publicou o livro no Brasil investia na produção de obras paradidáticas, destinadas especificamente à formação moral e intelectual da juventude. Já a editora alemã era especializada em livros religiosos. Dessa forma, tanto no Brasil como na Alemanha, Uoni-Uoni teve um caráter educativo.

A imagem do indígena foi largamente utilizada na construção de identidades, seja nos contextos históricos colonial, imperial ou republicano. Ligia CHIAPPINI (2005: 35), tratando do índio na literatura brasileira, sugere uma trajetória que parte do índio 
como objeto da observação, passa pelo indígena personagem de narrativas e chega, mais tarde, ao índio narrador: "escritores cultos tematizaram a questão indígena, falando pelo índio ou tentando fazê-lo falar, mas sempre através do filtro de um ponto de vista, embora diversificado, de branco e letrado". Por isso, a principal inovação do livro de Mario Baldi é que ele é narrado por um índio, obviamente um narrador ficcional, mas significativo do ponto de vista cultural e antropológico.

Para abordar a narrativa, proponho uma análise que compreenda o verbal e o visual como um exemplo de mixed media (MITCHELL 2005), uma mistura de imagens e palavras que definem, mas também limitam experiências de imaginação, relativização, compreensão, surpresa, aprendizado e memória.

\section{Pelo olhar de um índio}

Carol SCHLOSS (1987), que escreveu sobre a relação entre a fotografia e a literatura, introduz seu trabalho fazendo referência a Pig earth, primeira parte da trilogia Into the labours, de John Berger. Pépé, um dos personagens de Berger, que tinha o desejo de saber mais sobre sua própria cultura, afirma, numa mesa de uma casa do vilarejo: "I would like to know what life was like ten thousand years ago. [...] To see how the things we know today were first learnt.” (BERGER 1992:48-49)

A passagem reflete a necessidade de o observador se projetar para fora do mundo vivido, sempre que se deseja ter uma ideia diferente, mais ampla ou profunda sobre si mesmo. Existe uma impossibilidade inerente a toda vontade de autovisualização, somente superada numa situação hipotética de um ponto de vista externo, da construção de outro indivíduo observador: "That is what I would like to know if I was a crow on a tree watching [...] I'd look down at them like the old crow looks at us!", Pépé sugere que tem alguma ideia de como o corvo olha para ele mas o conteúdo do que veria permanece, ainda, misterioso.

A construção de um observador com objetivo de autovisualização estrutura também o trabalho literário de Mario Baldi. Na imprensa, o fotojornalista já havia narrado suas experiências entre os Carajá num estilo jornalístico e em primeira pessoa. No livro, as mesmas histórias e fotografias serviram para que Baldi revisitasse suas experiências através de outra voz narrativa. Como Pépé e o corvo, Baldi quer olhar 
pelos olhos de um índio e essa voz narrativa pode ser colocada em perspectiva. Mario Baldi, como branco e letrado, baseou seu ponto de vista nessa estratégia: o índio narrador contará a história. Mas fica a pergunta: sua própria história ou a história de Baldi?

Essa pergunta lembra a relação entre história e ficção, narrador e leitor. Paul Ricoeur (1997) escreveu longamente sobre isso. Para ele, tanto a história quanto a ficção devem ser separadas de um passado que aconteceu - o ter-sido que não se pode mais observar. "Essa crítica do conceito ingênuo de realidade aplicada à passadidade do passado exige uma crítica simétrica do conceito não menos ingênuo de irrealidade aplicado às projeções da ficção". (RICOEUR 1997: 274) Todo texto tem seu próprio mundo, fruto de uma vontade original, que ficará sempre em suspenso, à espera de uma mediação de leitura: "com efeito, somente pela mediação da leitura é que a obra literária obtém a significância completa”. (RICOEUR 1997: 275)

$\mathrm{Na}$ união do mundo do texto (sua estrutura interna) com o do leitor (recepção mediadora) Ricoeur identifica quatro elementos: o autor e o leitor reais; e o autor e o leitor implicados. Todos completariam o ciclo da experiência cultural:

O mundo do texto constitui relativamente à estrutura 'interna' do texto uma intenção absolutamente original. Mas temos de confessar que, considerado à parte a leitura, o mundo do texto continua sendo uma transcendência na imanência. Seu estatuto ontológico permanece em suspenso: em excesso relativamente à estrutura, à espera de leitura. Só na leitura o dinamismo de configuração encerra o seu percurso... Com efeito, do autor é que parte a estratégia de persuasão que tem como alvo o leitor. É a essa estratégia de persuasão que o leitor responde acompanhando a configuração e apropriando-se da proposta do mundo do texto. (RICOEUR 1997:275-277)

O autor real não tem muito peso na fenomenologia da leitura de Ricoeur. Sendo digno de biografia, ele seria apenas autor da estratégia de persuasão, cujo componente central é o autor implicado, aquele que se dirige, de fato, ao leitor. A voz narrativa é fruto da "parafernália de disfarces e máscaras de que se serve o autor real para se transformar em autor implicado.” (RICOEUR 1997: 279). Uma das estratégias para essa metamorfose autoral é a construção de um autor digno de confiança. A confiança, diz Ricoeur, está para a narrativa de ficção assim como a prova documental está para a historiografia. $\mathrm{Na}$ ausência de uma prova documental, o autor implicado propõe um pacto de leitura entre si e o leitor. Esse leitor ainda é implicado, ou seja, virtual. Está latente à espera que seja metamorfoseado em leitor real e, enfim, seja completado o ciclo. 
Essas ideias nos ajudam a entender o papel do narrador de Baldi. A primeira inovação do autor real, ao tratar da vida indígena, é a criação de um narrador indígena ficcional. Essa voz narrativa não era comum para o padrão da época. Em comparação, a coletânea de artigos Entre os Xavantes do Roncador (SouZA 1946), publicada por seu amigo e dupla de reportagem Lincoln de SouZA, definia já no título o lugar do homem branco, situado entre os objetos de observação.

Em certa medida, Mario Baldi tentou evitar a relação sujeito/objeto que estruturou o trabalho de Lincoln de Souza. Na verdade, ele não se opunha às abordagens dos trabalhos como o de Lincoln de Souza, já que suas próprias fotografias aparecem em Entre os Xavantes do Roncador e ele mesmo havia cultivado essa perspectiva nos artigos ilustrados que publicava. Ao mesmo tempo, é inegável que em Uoni-Uoni a estrutura de poder em relação aos povos indígenas do Brasil, exercida também pela autoridade de quem poderia falar pelos índios, foi em parte modificada. Assim, através de uma tentativa de relativização e compreensão, os meios de comunicar, de contar uma história, estão sob uma única voz e olhar, texto e imagem controlados por um índio ainda que inventado.

É interessante notar que Mario Baldi construiu sua voz narrativa a partir de provas documentais, exatamente aquilo que falta ao autor de ficção (na argumentação de Ricoeur). Nesse caso, as fotografias eram os indicadores infalíveis de que ele estivera entre os índios. No prefácio, parte em que o autor apresenta ao leitor a história e a forma como foi ela elaborada, percebemos que Baldi está mostrando as credenciais de alguém com tempo de vivência entre os índios e que viu os fatos de perto: "Baseia-se tudo em fatos autênticos". (BALDI 1950: 5-6) Ele poderia ter optado por continuar no mesmo tom do relato de viagem, como ele mesmo até então fizera. Mas quando a narração está para começar, outra voz é anunciada: "Deixo que ele próprio narre, na sua maneira 'engraçada' e afável, as suas aventuras e outras, que aconteceram nestas paragens, durante minha filmagem, entre estes amáveis índios Carajá.” (BALDI 1950: 5-6).

E assim começa a história: "Eu sou Uoni-Uoni” (BALDI 1950: 9). O pequeno índio narrador chamava-se Toilá, mas teve seu nome modificado para Uoni-Uoni pelo homem branco. A mudança se dá, na narrativa, por um rito de passagem duplamente significativo, já que é Baldi quem redefine a identidade expressa no nome do indiozinho e o episódio demarca na narrativa um novo momento na vida de Toilá/Uoni-Uoni. A passagem se baseia na percepção do branco: "Ele percebeu que eu tenho na pele da 
barriga, bem perto do umbigo, duas verrugas. - 'Que é isso?' perguntou-me. 'Uoni', respondi. Riu-se muito. - 'Ó meu pequeno amigo. Agora tu não serás mais Toilá. Vais chamar-te, daqui por diante, Uoni-Uoni'”. (BALDI 1950: 9)

Assim, o narrador começa a contar como e onde vivem os índios de sua aldeia, e deixa a história do tori para mais tarde. O narrador-narrado domina o tempo da narrativa, e escolhe o que contar e quando contar, sem deixar de explicar o quê, por seu julgamento, o branco não entende. Dessa forma é que descreve e justifica o modo de construção dos ranchos e a necessidade do deslocamento da aldeia de acordo com as estações do ano. Nessa construção, percebe-se uma estratégia do autor real, que, ao deslocar o discurso da terceira pessoa para a primeira, demonstra que apenas um mediador muito especial e dotado de autoridade poderia fazê-lo. Apenas quem observou a aldeia de dentro pode falar sobre ela, tal qual um índio, supostamente, o faria.

Ao assumir uma posição privilegiada no processo de mediação entre o público urbano e o mundo distante e diferente do sertão, o autor lança mão de artifícios narrativos que levam, ou almejam levar, o leitor a um contato o mais próximo possível do Outro. Suas intenções são claras desde o "Prefácio" à obra: produzir no leitor um sentimento de amizade e compreensão para com os índios. O vocabulário Carajá é largamente utilizado nessa tentativa de aproximação. Assim, branco é Tori, cachimbo é haricocó, e Araguaia, Beró-ô-cán. Escolha óbvia, se o objetivo é que o próprio índio conte sua história. Escolha eficaz, se o objetivo é criar um elo, mediado pela experiência do autor-fotógrafo, entre o leitor, figura eminentemente urbana, e o indígena. A narrativa não só versa sobre a alteridade, mas torna-se o espaço da alteridade. A sensação, para o leitor, é que está em diálogo com o Outro, sobretudo se atentar para as notas explicativas, ao fim do texto. Nelas, a entonação da escrita e a marca autoral se modificam, e o leitor passa a saber que quem enuncia o discurso, neste caso, é Mario Baldi.

Hoje há um barulho danado na aldeia. Que coisa terrível: o sol já está alto e as mulheres preparam a comida. A canoa do Sacrivá desce rapidamente o Beró-ô-cán, e aborda à praia. [Aqui Baldi insere uma nota] [...] Corremos os dois para a canoa e vimos uma cena horrível. Sacrivá tinha a seus pés o Zavahuri, gravemente ferido. (BALDI 1950:19)

$\mathrm{Na}$ nota referente ao trecho, lemos: "Isto aconteceu em 1934, perto da aldeia 'Mato Verde', nas imediações da embocadura do rio das Mortes. Foi-me contado assim pelo chefe dessa aldeia, o velho Tiaureti. O assassinado era o irmão dele". (BALDI 1950: 101) 
Pode parecer uma constatação sem muita importância, numa primeira aproximação, e é certo que o leitor precisaria percorrer a narrativa completa e todas as notas explicativas para ter tal sensação. Entretanto o trecho é elucidativo, pois permite ver o tipo de experiência que o narrador real tenta criar entre o narrador ficcional e o público, e a própria narrativa passa a abrir espaço para a alteridade.

Os aspectos da vida indígena eleitos para descrição são retirados do típico repertório etnográfico: modos de habitação, deslocamento da tribo de acordo com o clima, crenças e lendas da cosmogonia, cultivos, caça, costumes funerários, cerâmica. $\mathrm{O}$ que ocorre é o deslizamento para a fala do índio de um discurso de alteridade, originário do branco. Uoni-Uoni quer traduzir para os citadinos aquilo que estes querem ouvir do indígena. É oportuno lembrar, nesse sentido, a observação de Ligia Chiappini sobre os escritores cultos e bancos e sua prática de tomar a palavra no lugar do índio.

Não se trata de tomar o tex to como um retrato falho, ou como uma imposição de pontos-de-vista, mas sim de compreender os espaços de diálogo entre o índio e a suposta civilização moderna para a qual o livro foi escrito. É assim que Baldi ironiza alguns aspectos das sociedades urbanas, como seus modos de moradia. Uoni-Uoni relata que, ao olhar imagens de um livro do pai branco, um missionário católico, viu neste livro "ranchos com muitos buracos e uma porta; vi ranchos sobre ranchos. Diz o 'pai branco' que nas grandes aldeias onde ele vive se faz assim: porque fazem um rancho em cima do outro, não entendo! Há tanto lugar na terra!" (BALDI 1950: 18) A primeira parte do livro é rica em comparações e confrontos entre culturas. A alteridade do índio em relação ao branco irrompe na superfície da narrativa constantemente, como o evidencia outro episódio referido ao momento em que Uoni-Uoni folheia o livro do pai branco e descobre a escrita como suporte de memória:

[...] perguntei-lhe que significam as pequenas coisas pretas... Respondeu-me que é para a gente se lembrar do que outras gentes contaram antes, há muito tempo já... Quis ver se ele falava a verdade e narrei-lhe então uma história, pedindo-lhe que a desenhasse na folha. Depois de alguns dias pedi-lhe que tomasse a folha e visse nela as coisas pretas pequeninas, para que ele me repetisse a história como eu contara. Ele não me enganou não! Leu palavra por palavra, toda a história, como eu tinha contado no outro dia... Prometeu-me que, quando eu for maior, me ensinará a fazer as pequenas imagens... Mas eu não sei, não. Antes quero experimentar. Esperarei até que o "pai branco" volte novamente depois da próxima grande chuva. Se dessa vez ainda me contar a minha história olhando a folha branca, aí, sim, acreditarei nele e aprenderei como se faz isso. (BALDI 1950:16-18). 
É interessante como o autor abre espaço para o narrador interpretar e julgar um dos principais traços da diferença entre índios e brancos, a escrita, ao fazê-lo pôr à prova a eficácia da técnica. O trecho é ambíguo, já que, de certo modo, se distancia da opinião de que o indígena resiste à civilização por características intrínsecas de raça, ao apontar para um olhar de estranhamento, experimentação e julgamento do diferente, algo normalmente vinculado à atitude do branco frente ao Outro. Por outro lado, não esconde o fascínio do índio pela escrita, algo fartamente documentado na etnografia europeia e registrado, por exemplo, por Claude LÉVI-STRAUSS (1996). O outro exemplo põe frente a frente a ciência branca e as crenças indígenas quanto às doenças:

Meu pai, que acompanhou o 'pai branco', antes das três últimas chuvas na sua visita à nossa aldeia, contou-me que estas picadas dos mosquitos são as culpadas de nos sentirmos mal, de repente, como se um fogo nos devorasse o corpo, de tremer como os galhos das árvores de nossas matas, em meio às tempestades e suarmos em abundância. Ah, que coisa terrível é isso!... O meu tio, o grande pajé Kuhubara, diz que esta história do 'pai branco' não passa de mentira e que são os espíritos maus que entram no corpo dos homens e os atormentam. Nunca tinha ouvido coisa semelhante a essa: que os mosquitos podem fazer tantos e tão grandes males à gente. (BALDI 1950:10-12)

Esse é um trecho que joga com as expectativas do leitor. Primeiramente, este se depara com a posição compartilhada pelos letrados brancos, a de que a malária é transmitida pelos mosquitos. O leitor identifica-se com tal idéia e lê, em seguida, a explicação indígena de que os espíritos causavam a doença. O narrador, então, lança uma afirmação que o leitor letrado poderia atribuir a si mesmo: "Nunca tinha ouvido coisa semelhante a essa". Porém, essa coisa nunca ouvida é a ciência branca, já que os mosquitos como vetores da doença era uma ideia absurda para os índios.

A segunda parte da obra, intitulada "O meu irmão grande", é dedicada à narração do contato entre o tori e a aldeia Carajá. Nela, Baldi traz à tona a relação dialógica entre o índio e o branco, fazendo com que o Toilá, agora Uoni-Uoni, batize Mario com novo nome. Rito de passagem recíproco e simétrico, ainda que posterior, àquele em que Baldi muda o nome do menino indígena. "'Mas também vou dar-te um nome'. 'Qual?'. 'Vou chamar-te Haricocó'. 'Engraçado, que quer dizer isso?' 'Haricocó quer dizer cachimbo na língua Carajá. Nunca largas o cachimbo..."”. (BALDI 1950: 66). Assim, percebe-se que o autor tenta usar um artifício novo na representação do indígena, uma autonomia simulada no espaço criado pelo próprio autor, no qual o índio habita como observador. 


\section{Fotografias narradas}

O observador indígena também controla os sentidos da dimensão visual da narrativa. Nada melhor para arrematar a criação de um narrador-ficcional do que um índio que dá a ler as fotografias da obra, pois as legendas das imagens são também redigidas no registro narrativo que o autor pretende que seja o do menino índio. É um fator central na experiência etnográfica e fotográfica.

Partindo da proposta de oficialização da etnografia enquanto prática ao longo da trajetória de Mario Baldi, podemos identificar a construção de um discurso baseado no que James ClifFord (1998) chamou de autoridade etnográfica. Para ele, "o modo predominante e moderno de autoridade no trabalho de campo é assim expresso: "você está lá... porque eu estava lá””. (CLIFFORD 1998: 18). A declaração inicial, existente na maioria das etnografias, de que "eu estive lá", ou como Baldi formula em seu prefácio, “durante os anos de 1934-35, percorri os vastos sertões...", (BALDI 1950: 5) deixam claro para o leitor que a narrativa surgida da experiência apoia-se no pressuposto de que "a experiência do pesquisador pode servir como uma fonte unificadora da autoridade no campo" (CLIFFORD 1998: 34) e, por conseguinte, na obra textual. Tal experiência, para ser completa, deve englobar algumas atitudes, entre elas o esforço para alcançar a cumplicidade e a amizade entre o pesquisador e o nativo, um sentimento que leva o etnógrafo a encarar como seu o povo estudado. Mas Clifford chama a atenção para o fato de que o uso da expressão "meu povo", remete à "minha experiência" de estudo etnográfico. (CLIFFORD 1998: 38) Para garantir a autoridade de seu relato, Baldi, não por acaso, afirma que

[...] a amizade da gente da aldeia de Diahima para comigo foi ao ponto, o que me envaidece sobremaneira, de me aceitarem como um dos seus, portanto, me considerarem também Carajá e me terem pintado o rosto com os desenhos do clã do Cacique Diahima. (BALDI 1950:6) 


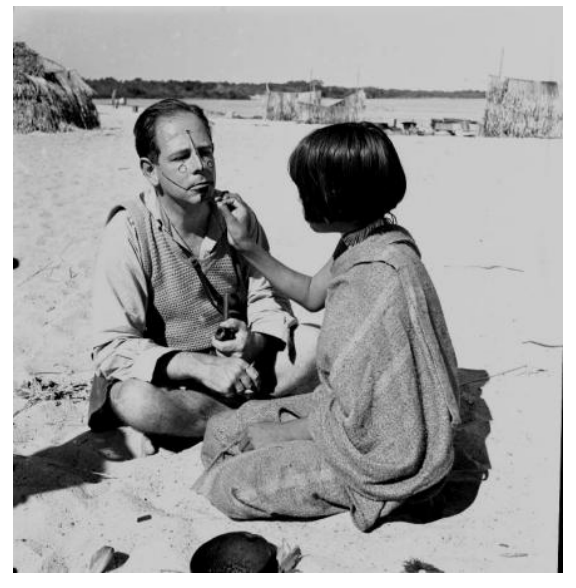

Figura 1: AVELLAR, Doralice (?). Neg. 6x6 Baldi n5027. Folha-contato Carajá 1938.

Legenda do livro: "No dia seguinte, minha irmã pintou solenemente na cara do irmão grande os sinais de nosso clã", 95 .

Na imagem, vemos Mario Baldi no momento que considera ser sua aceitação pela tribo Carajá (Figura 1). A fotografia foi provavelmente feita por Doralice Avelar. Temos aqui o argumento visual, com sua característica veracidade fotográfica, daquilo que, para a prática de Baldi, consiste no argumento de sua autoridade: ser aceito como alguém da tribo e, em consequiência, ser considerado por seus leitores como alguém competente para mediar esses dois mundos.

Nas séries originais, as fotografias formam um inventário das expedições fotográficas. Na série do livro, formam um universo próprio, no qual o pequeno índio indica o caminho a ser percorrido. ${ }^{2}$ Nas séries originais, a descrição física dos negativos utilizados no livro é a seguinte: 2 negativos no formato $6 \times 9 \mathrm{~cm} ; 1$ negativo no formato 4x6cm; 2 negativos em 24x36mm; e 37 negativos em 6x6cm. A maioria das imagens foi feita, portanto, numa Rolleiflex, que produzia um negativo quadrado.

\footnotetext{
2 Baldi produziu todas as imagens utilizadas no livro antes de construir sua narrativa, com exceção, talvez, da imagem do pajé da aldeia de Malohá, datada de 1946-47. Se ele começou a escrever o livro antes disso, é a única fotografia feita enquanto o livro se desenvolvia.
} 


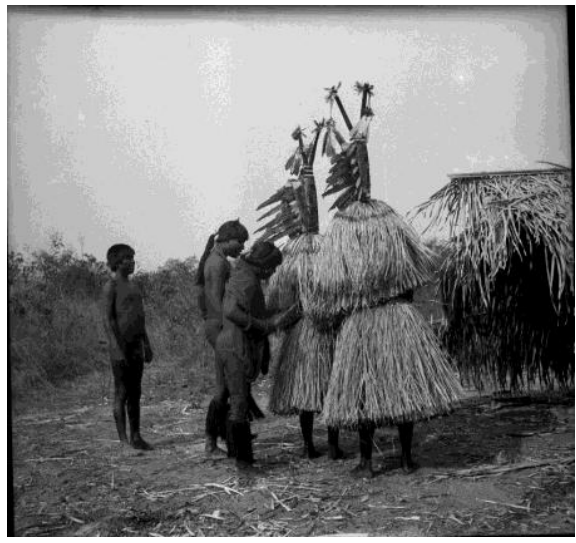

Figura 3: BALDI, Mario. Carajá / Huruaná Dansa. 1936. Neg. 6x6 Baldi n4922 Coleção Mario Baldi, Welt Museum Wien

Legenda do livro: "Eu, porém, dirigi-me a casa dos bichos para ver como se vestem os guerreiros que executam o horuanã", 36 .

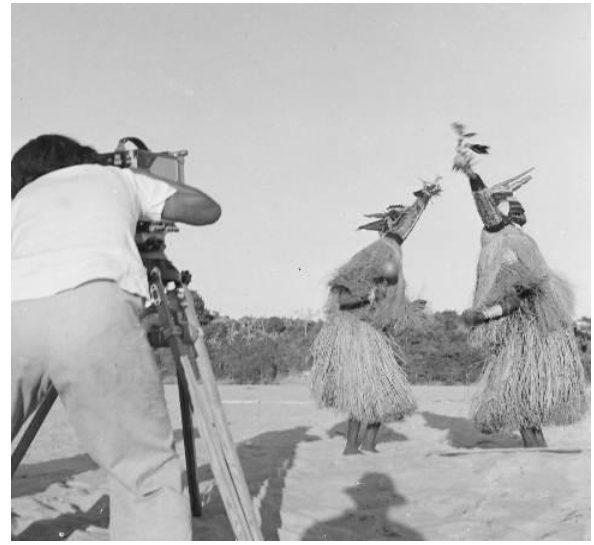

Figura 2: BALDI, Mario. Huruanatanz (Cult Tanz) [Dança do Huruana (Dança de Culto)]. 1938. Neg.6x6. Baldi n4972 Folha-contato Carajá $1938 \quad n^{\circ} 12$ Reprodução espelhada. Coleção Mario Baldi, Weltmuseum Wien.

Legenda do livro: "E, um belo dia, Kuhubara até mesmo mandou realisar danças dos bichos em honra dos Tori”, 96

As imagens dessa câmera favoreciam a perspectiva que Baldi utilizou no livro, pois o operador normalmente segura a câmera Rolleiflex à altura da barriga. Assim, as fotografias se parecem com o olhar de uma criança, algo semelhante à visão que o pequeno índio tinha de seu mundo. A série das imagens funciona como uma sequência de olhares de Uoni-Uoni, como ele observa e conta sua história, revelando os mistérios e idiossincrasias de seu povo. Em algumas imagens, sugere-se que não mais o fotógrafo, porém um índio permite que olhemos através da visão de um insider. Nas fotografias que apresento, incluí os dados de arquivamento elaborados pelo fotógrafo, de modo que se podem ver as novas informações e reinterpretações a elas adicionadas pela edição no livro.

A figura dois é um bom exemplo da ressignificação que Baldi dá às fotografias do livro (Figura 2). Foi produzida em 1936, numa viagem com D. Pedro de Orleans e Bragança e sua família. Representando a preparação para a dança do Horuanã, no livro ela é narrada por Uoni-Uoni, que buscava observar o vestir dos índios para o ritual. O olhar do narrador está na direção dos ombros dos observados, é uma criança que nos dá a ver a atividade dos índios. 
O autor, na tentativa de construir uma observação honesta e legítima, nunca suprime seu próprio interesse em determinados dados culturais, refletidos nos interesses do leitor comum dos centros urbanos. Os olhares de Uoni-Uoni, ao fim, são seus olhares, não os de Toilá. Entretanto, são narrativas criadas a partir de histórias contadas por índios, Toilá, Tiaureti e outros. Baldi parece ter constatado a impossibilidade de um olhar de mão única, de um centro de observação e de objetos observados. Seu livro sugere uma negociação entre o leitor e índio, num proposital emaranhado de pontos de vista e vozes, em que a alteridade poderia ser confrontada de maneira positiva.

Uoni-Uoni observa a filmagem feita por Doralice Avellar (Figura 3). Seu campo de visão é o de uma criança, está fora do ritual, por lei dos próprios Carajá. Na parte inferior da imagem, vemos a sombra do fotógrafo. Baldi captura um indício de sua presença, de sua própria observação. Está com o chapéu de viagem, o mesmo que abre o livro na cabeça de Toilá, quando se transforma em Uoni-Uoni (Figura 6). A presença de outros sujeitos apontam justamente para uma brincadeira com realismo visual, no qual a imagem surge como uma projeção objetiva do mundo visível, sem a presença do sujeito que a cria. Aqui, tanto a cineasta como a sombra do fotógrafo inscrevem, como uma assinatura, o produtor da imagem na própria imagem, admitindo a separação entre a fotografia, o filme de Doralice e o mundo observado.

A liberdade narrativa de Baldi, usufruída plenamente num texto não jornalístico, permitiu que utilizasse imagens de outros índios como ilustrações do narrador UoniUoni. A fotografia da criança com o chapéu do fotógrafo foi arquivada por Baldi como uma imagem de Typos. Em sua lógica, existiam outros indivíduos que se adequavam à mesma classificação. $\mathrm{O}$ artifício funcionou por duas razões: não se tratava de um índio real (o filho do cacique chamava-se Toilá ou Cacequi, como está no original datilografado), mas de um personagem narrador; e as diferenças e semelhanças étnicas foram consideradas por Baldi, numa tradição ampla e bem antiga, como um dado visual.

Nas imagens seguintes, temos Uoni-Uoni em vários tempos (Figuras 4 a 6). A figura seis é uma das mais eloquentes do livro, pelos dados de arquivamento que apresenta. Baldi anota que o menino na imagem é irmão de Uoni-Uoni, mas o livro afirma que se trata do narrador da história. Assim, podemos dizer que a fotografia não veicula uma única representação do real, pois trata-se sempre de uma escolha realizada no contexto da arena discursiva da qual participa. Nesse sentido, vale observar a 
primeira imagem do livro, que é a única fotografia sem legenda. Na verdade, sua legenda é a primeira frase da narrativa: "Eu sou Uoni-Uoni".

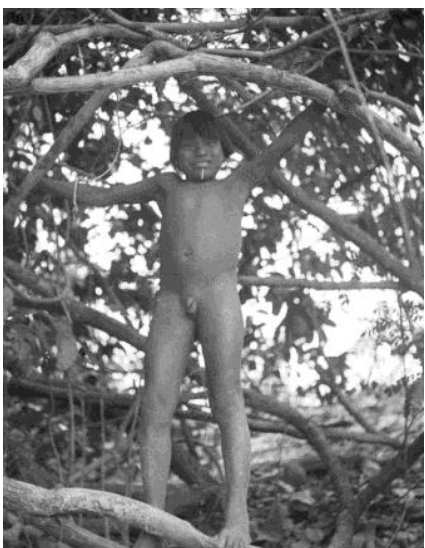

Figura 5: BALDI, Mario. Carajá-Knabe Ilha Bananal Dorf: S. Isabel Expedition 1936" / "Caraja" / “Tarzan' Carajaknabe Dorf S. Isabella Bananalinsel. 1936. Neg. 6x6 Baldi n³231. Coleção Mario Baldi, Weltmuseum Wien

Legenda do livro: "Ó grande e sabido Tori, então não sentes pelo cheiro que lá na frente está uma cobra?", 91.

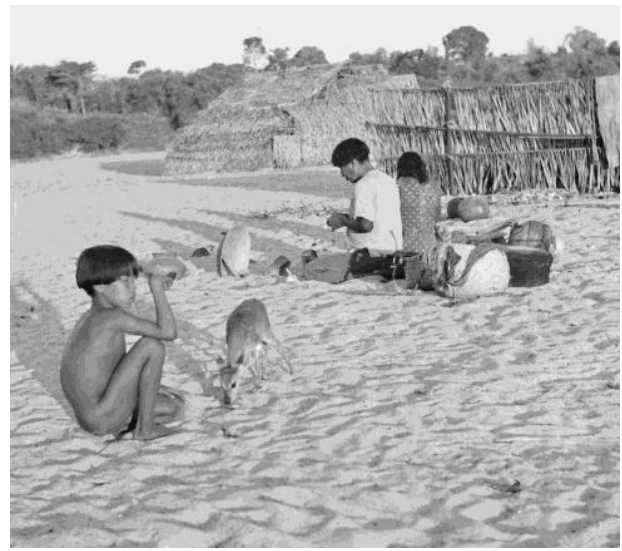

Figura 4: BALDI, Mario. "Caraja" / "Bruder von Uoni-Uoni" / "Garoto Carajá com veadinho amansado". 1938. Neg. 6x6 Baldi n4960. Folha-contato Carajá 1938 $n^{\circ} 11$. Coleção Mario Baldi, Weltmuseum Wien

Legenda do livro: "Uoni-Uoni com seu veadinho manso", 17.

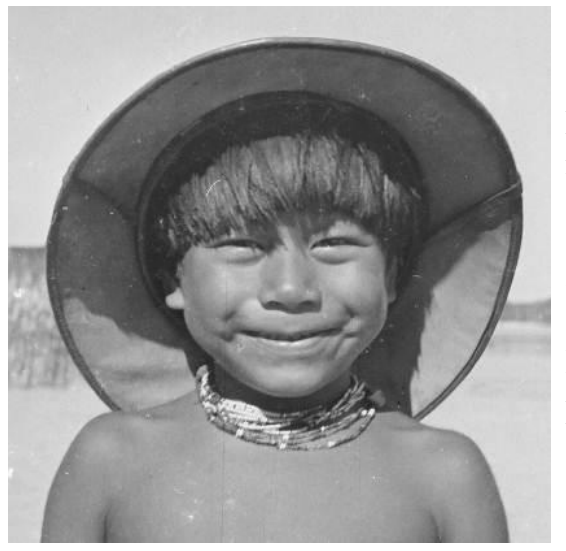

Figura 6: BALDI, Mario. "Uoni-Uoni mit meinem Hut" / "Filho do chefe Caraja com nome UONI-UONI". 1938. Neg. 6x6 Baldi n4884 Folhascontato Typos ô $n^{\circ} 2$, Carajá $1938 n^{\circ} 1$ e Carajá $1938 n^{\circ} 4$. Coleção Mario Baldi, Weltmuseum Wien.

Legenda do livro: s/l

Os dados de arquivamento da fotografia, elaborados pelo próprio fotógrafo, registram: "Uoni-Uoni com meu chapéu" ("Uoni-Uoni mit meinem Hut”). Um ato despretensioso, talvez uma brincadeira, serviu perfeitamente para produzir Uoni-Uoni. Assim percebemos quem é o indiozinho: alterego de Baldi, é um observador que serve à sua abordagem fotográfica. 


\section{Os últimos índios na Água Grande}

Entre a versão brasileira e a versão alemã há algumas diferenças que merecem destaque. Os originais de Uoni-Uoni, datilografados por Baldi, foram feitos em alemão. A versão brasileira foi traduzida por A. Corrêa e contou com 42 imagens. ${ }^{3}$ Já a versão alemã, publicada pela Bastion-Verlag, apresenta 24 imagens e tem estrutura diferenciada, com subtítulos e um mapa para que os leitores europeus identificassem onde se passava a história.

O conteúdo verbal dos originais é bem parecido com o publicado nos livros, salvo mudanças pontuais de algumas palavras por sinônimos e adição ou subtração de preposições e palavras de ênfase. Portanto, o texto datilografado em alemão é realmente a matriz das duas versões publicadas. Uma diferença importante entre elas está no título. Enquanto em português o narrador e sua história são privilegiados (Uoni-Uoni conta sua história), em alemão Uoni-Uoni faz parte de uma tribo quase lendária, "os últimos índios na Água Grande" ("die letzten Indianer am Grossen Wasser"). ${ }^{4}$

É uma diferença que modifica o efeito de leitura. Em português, o índio não se preocupa em traduzir os termos da sua língua. O autor real introduz notas ao fim do livro, para que o leitor os entenda. Já em alemão, o próprio narrador os explica logo que são mencionados. Em português temos duas vozes claramente distintas e em alemão apenas uma. Vejamos o trecho inicial da narrativa, nos dois idiomas. Em português:

Eu sou Uoni-Uoni, filho do chefe de nossa aldeia, que fica situada num banco de areia, no meio do Beró-ô-cán (1). Não tive sempre êste nome. Bem, na verdade, isto não é um nome, não é mesmo?... Chamavam-me antes Toilá. Um dia, porém, chegou a nossa aldeia um tori (2). (BALDI 1950: 9)

As notas para este trecho encontram-se ao final do texto: “(1) Beró-ô-cán: nome Carajá para o rio Araguaia. Literalmente: a água grande. (2) Tori: como chamam os Carajá os brancos. As vezes significa: branco, estrangeiro, cristão, forasteiro". (BALDI 1950: 101)

Em alemão:

Ich bin Uoni-Uoni, Sohn des Häuptlings unseres Dorfes auf der Sandbank inmitten des "großen Wassers". Sie nannten mich nicht immer so, den das ist ja gar kein richtiger Name. Sie riefen

\footnotetext{
${ }^{3}$ A imagem dos Licocós, os bonequinhos feitos pelos carajá, é uma montagem de 2 fotografias, por isso a contabilizei como uma imagem apenas. Foram, portanto, utilizadas 43 fotografias originais no livro.

${ }^{4}$ Água Grande é a tradução para Bero-O-Can, como os Carajá chamavam o Rio Araguaia.
} 
mich früher Toila. Aber eines Tages tauchte in unserem Dorfe ein Tori, ein weißer Fremdling, auf. (BALDI 1951: 12).

O editor da versão alemã, Konrad Heinrich Simons ${ }^{5}$, optou por incorporar as informações ao texto, talvez para torná-lo mais fluente. Assim, o texto alemão busca outro efeito de "autenticidade", diferentemente do almejado pelo texto em português. Neste último, temos um narrador que só explica algo quando interrompido pelo interlocutor, o que equivaleria à dúvida do leitor e sua pausa para consultar as notas. Vale ressaltar que os originais datilografados contam com notas explicativas, o que foi mantido apenas na versão brasileira. Para Baldi, a autenticidade da narrativa residiria em simular um narrador despreocupado com explicações pormenorizadas sobre sua própria língua. Qualquer voz "científica" deveria ser separada do texto. A edição brasileira tem um traço de estudo etnológico, demarcado pela voz de autoridade do texto das notas, que citam, por vezes, trabalhos de etnólogos como Herbert Baldus.

Em relação às fotografias, é interessante notar que a versão alemã apresenta apenas 24, pouco mais que a metade do número de imagens da versão brasileira. Poderíamos supor que o motivo do corte de imagens tenha sido o custo da edição. Porém, a edição alemã é mais luxuosa, com lombada em tecido e duas capas, uma dura, propriamente da encadernação, e outra que abraça todo o conjunto, com uma ilustração, títulos e um mapa do Brasil na segunda orelha da capa. Enfim, a Bastion-Verlag não parece ter economizado na confecção do livro. Por que o teria feito no conteúdo visual? Para esclarecer a questão, apresento algumas edições realizadas.

A primeira informação importante é que Baldi selecionou 40 fotografias, para as quais preparou legendas em alemão. À primeira seleção adicionou mais duas e, na publicação, substituiu mais outra. É razoável supor que o autor selecionara as 42 imagens para compor o livro em todas as suas edições, pois as fotografias cooperam com o sentido da narrativa. Como Uoni-Uoni dedica metade da sua história ao cotidiano indígena anterior à chegada dos brancos, as fotos representam os costumes dos índios, como sepultam os mortos, como fazem bonecos de barro, como usam o pilão, como constroem as malocas sobre o banco de areia no inverno, como se vestem para rituais, como pintam os remos etc.

\footnotetext{
${ }^{5}$ Konrad H. Simons foi um escritor alemão da primeira metade do século $\mathrm{XX}$, dedicado a histórias infanto-juvenis, normalmente narrativas de aventura.
} 
A segunda parte do livro narra a chegada de um grupo estranho de brancos e mestiços, dentre os quais estão Mario Baldi e Doralice Avelar. As fotografias agora retratam não só os índios, mas a interação entre eles e o grupo de visitantes. Há o acampamento dos Tori (brancos), as máquinas de filmar, as roupas diferentes dos visitantes etc. Enfim, para cada assunto narrado apresentam-se fotografias correlatas.
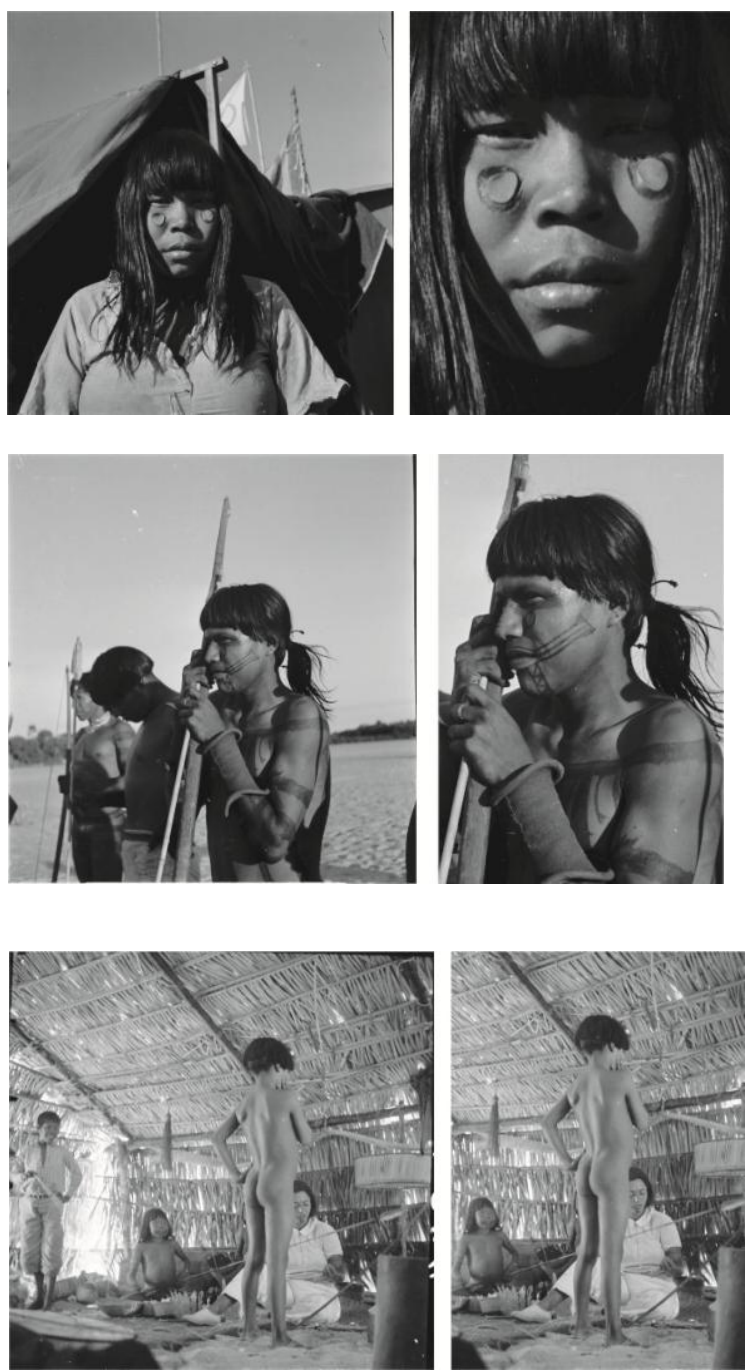

Figura 7: s/l. 1938. Neg. 6x6 Baldi no4901. Folhacontato Carajá 1938. Coleção Mario Baldi, Weltmuseum Wien

Legenda do livro: "Hrêrai, minha mãe, ama-me extremamente e está sempre a velar por mim”, 93

Figura 8: BALDI Mario. "Caraja” 1938. Neg. 6x6 Baldi n4992. Folha-contato Carajá 1938. Coleção Mario Baldi, Weltmuseum Wien

Legenda do livro: "O cacique Diahima, meu pai, é quem dirige as expedições de guerra e as caçadas. Sua palavra é ouvida com respeito no Conselho dos Guerreiros", 13

Figura 9: s/1. 1938. Neg. 6x6 Baldi n4944. Folha-contato Carajá 1938. Coleção Mario Baldi, Weltmuseum Wien

Legenda do livro: "Uoni-Uoni presenteia Behederu com uma flecha de caça", 64

Sobre a edição das fotografias, elas ajudam a construir uma imagem purificada dos índios. Quando a influência da chamada "civilização" fica muito explícita, edição entra em cena, como no caso das roupas de brancos que alguns os índios usavam (Figuras 7 a 9). Quando Baldi fez as fotos, talvez essa mistura de costumes fosse interessante de ser registrada. Para o livro, não tanto. Era preciso mostrar um índio "mais índio", enfatizando o contraste e o encontro de sociedades. 
Nesse sentido, a seleção das fotos, as edições e a distribuição das imagens entre as duas partes do livro são partes de um todo narrativo. Na versão alemã essa construção ficou um pouco prejudicada. Localizando as imagens excluídas, descobri que todas as que registravam o corpo nu dos índios foram rejeitadas ou bastante editadas. Seios ou nádegas, essas femininas ou masculinas, não deveriam ser mostrados. O mais perto que os alemães chegaram de mostrar o corpo indígena foi na fotografia de "Uoni-Uoni com o seu veadinho manso". Seu pequeno corpo de criança aparece de perfil, evitando o confronto com o leitor. Compare-se essa imagem com a que representa o esquartejamento do pirarucu, grande peixe dos rios brasileiros (Figura 10). No original, Baldi incluiu três pessoas na foto. Uma vai caminhando ao fundo e se distancia da cena. É um dos mestiços que chegaram com o grupo dos brancos. Dois índios protagonizam a ação. Na direita, há um índio agachado com seu facão. À esquerda, outro começará o trabalho para dividir o peixe em pedaços.
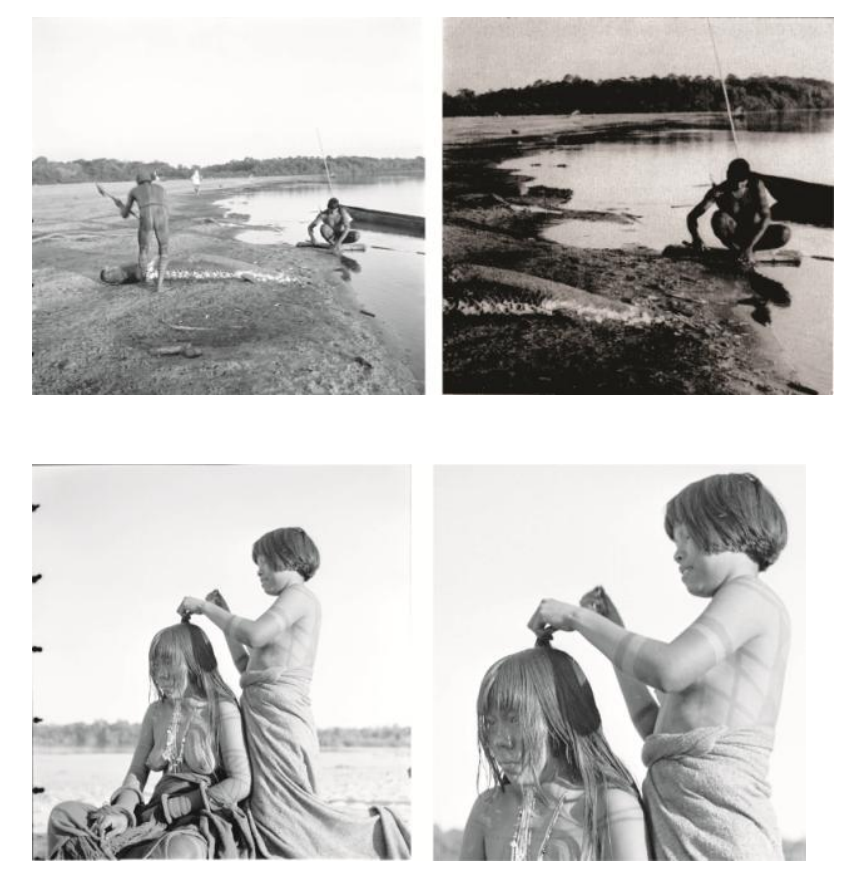

Figura 10: "Caraja" 1938. Neg. 6x6 Baldi $\mathrm{n}^{\circ} 5002$. Folha-contato Carajá 1938. Coleção Mario Baldi, Weltmuseum Wien

Legenda do livro: "A grande custo o gigantesco pirarucu foi trazido a aldeia e está sendo postejado", 53

Figura 11: "Caraja" / "Haarpflege". 1938. Neg. 6x6 Baldi no4964. Folha-contato Carajá $1938 n^{\circ} 11$. Coleção Mario Baldi, Weltmuseum Wien Legenda do livro: "Durante dias e dias, nossas moças se enfeitaram, porque cada qual pretende ganhar o cobiçado prêmio", 88 

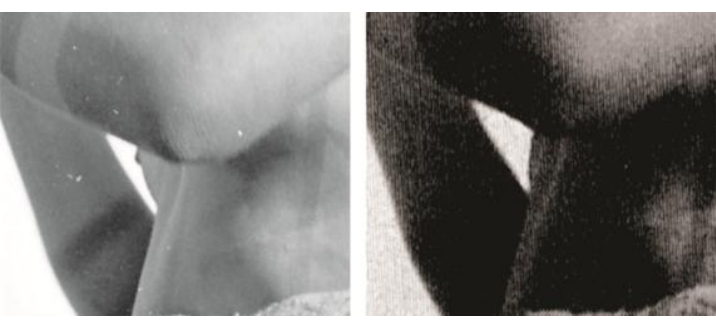

O corte da fotografia na versão brasileira suprimiu a parte superior e inferior, horizontalizando a imagem. Mas os três figurantes ainda estão lá. Já na versão alemã, o atrativo que Baldi quis dar a

Figura 12: Detalhe da edição anterior

imagem, enfatizado na legenda "a grande custo o gigantesco pirarucu foi trazido à aldeia e está sendo postejado", foi em grande parte perdido. $\mathrm{O}$ índio de costas, nádegas frontalmente direcionadas ao observador, não permitia retoques. O tamanho do peixe, que era percebido em relação ao corpo do índio, não pode ser tão bem percebido. A figura que se afastava da cena desapareceu por algum motivo. Mas o efeito foi, de qualquer maneira, ruim. Sua presença poderia levar-nos a imaginar que ajudara a trazer o peixe "a grande custo". Se a foto não ficou completamente vazia, foi excluída boa parte dos elementos de interpretação que poderia conceder ao leitor.

Outro exemplo pode-se encontrar na fotografia das duas índias que se ornamentam para o concurso de beleza (Figuras 11 e 12). O fotógrafo produziu um registro dos colares, pinturas corporais e adornos de braço. Com pequenos cortes no entorno da cena, a edição brasileira a publicou quase intacta. Já na Alemanha, os seios foram censurados e, junto com eles, os adornos de braço, parte das pinturas corporais e dos colares. O seio direito da índia à direita da foto também foi editado e apagado com retoque.

Na verdade, essas edições, cortes e retoques não são surpreendentes. A BastionVerlag era uma editora católica especializada em livros religiosos. Ademais, UoniUoni... tinha realmente um tom infanto-juvenil e, para os alemães, alguns conteúdos parecem não ter sido considerados apropriados. No conjunto das 18 fotografias excluídas, 15 registram nudez indígena. Entre essas, 12 registram nádegas e/ou genitálias masculinas e três registram nádegas e/ou seios femininos. Não há imagens de genitálias femininas, as mulheres do grupo visitado por Baldi em 1936 e 1938 usavam coberturas de panos amarrados na cintura.

É interessante que a nudez indígena não tenha sido censurada no Brasil. No imaginário tupiniquim o índio era uma extensão da natureza e o olhar do observador estaria livre de censuras. 


\section{A indiologia como infância da humanidade}

Para os críticos da época, o trabalho de Baldi tinha seus méritos. A coluna "Fora do Prelo", da Revista da Semana, definiu assim o livro:

Ainda agradecemos à Melhoramentos 'Uoni Uoni conta sua história', de Mário Baldi, livro ricamente ilustrado, em cujas revelações dum indiozinho muita coisa aprende a respeito da vida e dos costumes de nossos selvagens. A naturalidade, o tom sincero da narrativa, além dos pontos diretamente fixados pelo autor, como sagaz observador da civilização dentro das matas, junto da tribo Carajá, dão a esse livro um realce incomum em nossos estudos de gênero. (REVISTA DA SEMANA 1952 a)

A mesma revista publicou uma pequena lista de títulos e autores que faziam parte do que chamava de indiologia. Os livros seriam exemplos do interesse do homem civilizado "pelos sêres que lhe recordam o passado, os estágios dos avós, os primitivos parentes”, uma atitude semelhante à de Pépé, de John Berger. (REvisTa DA SEMANA 1952 b) Entre os títulos está Mario Baldi, com seu Uoni-Uoni conta sua história. Naquele mesmo ano, a editora do livro anunciava ao preço de $\operatorname{Cr} \$ 28,00$ o livro cujo narrador "é um ìndiozinho carajá, um brasileirinho da selva. Em linguagem muito pitoresca e colorida, conta ao estudioso homem branco a vida de seu povo". (EDITORA MELHORAMENTOS 1952).

Nas três mini-resenhas o valor do trabalho está nos fatos narrados a partir de um observador privilegiado, que pode ser o autor e seu olhar treinado ou o narrador construído, o índio que equivale ao informante do estudioso branco. Duas críticas mais profundas foram escritas em alemão e publicadas no Deutsches Wochenblatt. Numa delas, o autor destaca a escolha de Baldi por basear sua narração na lógica do pensamento indígena. Usa como exemplo um trecho do livro, fiel à forma como os carajá contam os números e o tempo: "Einige Tage später bringen sie von dort so viele Krieger heraus, wie ich Finger habe an den Händen und Füßen und noch zwei mehr”. (BALDI 1952: 22). Com isso o livro produziria um contato mais direto entre leitor e índio. O autor da resenha, que assina Dr. C. E., captou algo mais profundo no texto de Baldi, que subjaz à narração e às fotografias: o fato de que a história de Uoni-Uoni representa a história dos encontros étnicos típicos do Brasil. O Dr. C.E. toma a liberdade de pedir a Baldi que continue a permitir que o indiozinho conte sua história:

Man möchte nur wünschen, dass Baldi ein zweites Büchlein als Fortsetzung folgen lasse. Es wäre leicht möglich, dass der kleine Uoni, mit einem primtiven Kahn den 
Tocantinsfluss hinunterfährt, durch die herrlichen Wälder an den Schlangenfluss Moju kommt, dort trifft er zwar nicht den "weissen Vater", dort käme er zum "aba una" - zu einem "Schwarzen Vater" und könnte mit einigen Carajás und Camaranginindianern den schwarzen Panther erlegen. (C.E. 1953)

Já que Uoni-Uoni convivia com Carajá e Tapirapé, já que fizera amizades com os brancos, poderia então muito bem encontrar agora os negros e outros índios mais. Do ponto de vista da narrativa como um encontro entre culturas, o livro ganha uma nova roupagem, situando-o na tradição da indiologia.

Em 1943, Angyone Costa publicou o livro Indiologia, uma série de reflexões sobre o índio e suas representações em vários tempos da história do Brasil. (CoSTA 1943). Para o autor, a indiologia seria uma abordagem geral dos indígenas e de seus costumes e contribuições à formação do Brasil como um povo. Angyone Costa foi professor de arqueologia do curso de museus do Museu Histórico Nacional, no Rio de Janeiro. Para ele, era necessário considerar o índio uma das raças formadoras do povo brasileiro. Costa assume uma posição hostil às influências europeias e defende a independência americana dos modelos do Velho Mundo. A indiologia seria uma ciência que viria a suprir o mau uso da herança deixada por Rondon e sua obra:

A obra admirável de Rondon, realizada com devotados companheiros em quase quarenta anos de vida passada nos sertões, da qual nos ficou um material imenso, que devia ter servido a base à organização de um instituto de pesquisas sobre o indígena, subsiste apenas na paixão apostolar desse mesmo Rondon e dos seus mais próximos discípulos, mas não foi utilisada como documentação, em seu conteúdo científico, para a formação de um centro especializado que viesse despertar mais vivamente o amor à terra e ao homem americano, que uma arte e uma ciência européia subverteram pela base, transformando o brasileiro num espírito de cultura exclusivamente européia, mas adaptado sinão totalmente ignorante das condições ambientes das Américas. (COSTA 1943: 9)

Escrito em 1943, já declarada a guerra ao Eixo e com a política da boa vizinhança em curso, Indiologia louva aos Estados Unidos da América, "essa maravilhosa flôr de civilização". (COSTA 1943: 12). Costa define, então, a situação do brasileiro:

Nós, brasileiros, começamos por não constituirmos uma raça e erramos quando festejamos um dia da raça, que vem a ser assim a celebração de uma cousa que não existe. Biologicamente, quando muito estamos formando um povo, um grande povo, se o quizerem, nunca uma raça, que não pode ser o trabalho da miscigenação de três séculos de confusas etnías, como aquelas que predominaram na nossa composição, índios do litoral, lusitanos da Iberia e das ilhas, negros de todos os grupos da costa da África. O mulatismo nacional não gosta que se fale alto quando se trata de tais problemas e, pôr um recalque que se formou às primeiras lombadas do chicote na 
Lopes, M. B. - Indiologia brasileira

senzala, corre a dizer-se caboclo e a envergonhar-se do pobre negro, que um tão grande contingente de bondade e dedicação soube imprimir à nossa alma. (COSTA 1943:13)

Costa ainda afirma que o mulatismo nacional vive

[...] acabrunhado pelas origens afras, numa situação de estranho na própria terra, ... vivendo de acordo com as inclinações espirituais que a educação européia lhe imprimiu, sêr inadaptado e em revolta disfarçada, sempre voltado para a Europa. (COSTA, 1943:13)

O autor avalia que o problema é educacional e de formação defeituosa, e somente a superação dessa postura subserviente à Europa seria capaz de fazer com que os brasileiros sintam “o espírito da nossa América”. (COSTA 1943: 13). A resposta ao problema encontra-se na indiologia, pois ela considera o índio o verdadeiro dono da terra e seus saberes advêm duma existência em simbiose com ela:

Neste momento em que se procura imprimir uma orientação nacionalista ao sentido da nossa vida objetiva, a questão do índio é precípua. Não chegaremos a ser um grande país, realmente com espírito e formação nacional próprios, se não nos orientarmos, social e politicamente, fora dos moldes alheios, numa firme diretriz americana, com sentido de amor à terra, de compreensão e de valorização do índio, seu legítimo dono... No ambiente americano e, mais precisamente, no ambiente brasileiro, o homem terá que viver em legítima fusão com a terra, se quizer construir uma civilisação. (COSTA 1943: 12-14).

No contexto histórico da primeira metade do século XX, uma das tônicas do discurso sobre alteridade cultural indígena era a ideia de extinção de um passado de ouro. Seja de uma perspectiva etnológica ou jornalística, os textos muitas vezes salientavam o perigo do desaparecimento dos índios. A ideia fazia uma manobra no tempo. Ao passo em que os índios eram definidos como grupos contemporâneos, eram projetados a um passado original, à infância da humanidade.

Delimitando os troncos culturais dos quais o povo brasileiro descendia, a indiologia consistia de um projeto educativo, como definiu Angyone Costa. Com vestígios arqueológicos, pesquisas de campo ou investigações jornalísticas, a indiologia era feita por indivíduos que deixavam lições a partir de suas experiências. Nesse caso, o leitor se sente, ao mesmo tempo, contemporâneo e versão atual de um ser primevo.

Numa outra publicação da mesma "escola indiológica", Herbert Baldus, importante etnólogo alemão e amigo de Mario Baldi, apresentou o trabalho fotográfico de Manoel Rodrigues Ferreira: 
Eis um conflito para nós, os amigos da humanidade, o conflito que cada um de nós cria e alimenta no próprio peito: saudamos ruidosamente o Novo Brasil, o Brasil dos céus cruzados por aviões e controlados pelo rádio, e sonhamos em silêncio com o Velho Brasil, o Brasil do Aleijadinho e da mata virgem. Marchando para Um Mundo Só é o Novo Brasil que alcança e esmaga os mundos do Velho, aquêles mundos que tanto poderiam ensinar-nos, ainda, acerca das possibilidades da alma humana, e tanto poderiam aumentar os encantos da heterogeneidade dos bípedes não alados. (BALDUS 1951: 2).

Os autores bebiam ainda nas fontes de um romantismo melancólico e algo pessimista. Não queriam admitir que esse mundo velho desaparecesse e, se o faziam, registravam seus pesares. Influenciados por uma etnologia que evitava os processos de mudança cultural, faziam questão de registrar tudo o que remetia ao índio tradicional. Continuando sua apresentação das imagens de Ferreira, BALDUs lembra que

[...] a presente coleção de fotografias tiradas pelo engenheiro Manoel Rodrigues Ferreira, além de impressionar pelo louvor estético, representa preciosa contribuição para o conhecimento dos xinguanos... O amante da vida e dos vivos em geral ficará encantado pela multiplicidade de facêtas de um mundo aparentemente tão estranho e, na sua essência humana, tão ligado ao nosso. A publicação dessas fotografias é, portanto, mais um passo para aproximar o coração do Brasil do coração dos brasileiros. (BALDUS 1951: 2).

Logo adiante, o engenheiro e bom fotógrafo Manoel Rodrigues FERREIRA não esconde a clara escolha que fez:

Os índios são aqui mostrados pela maneira como viviam seus antepassados, livres da influência do civilizado. As fotografias têm um caráter eminentemente documentário, registrando as atividades indígenas, tendo sido evitado mesmo que a presença da câmara os pudesse perturbar. (FERREIRA 1951: 5).

Devemos registrar esse jogo de tempos, o tempo das fotografias e o tempo ao qual elas fazem referência. As imagens foram produzidas no contexto da Marcha para o Oeste, quando o projeto de ocupação territorial, modernização e industrialização era um projeto nacional. Já os índios que aparecem nas imagens não são índios de hoje, são atores de uma peça sobre seus antepassados, sobre o passado Brasil, aos poucos transformado pelo avanço do moderno. Herdeira do humanismo positivista do "morrer se preciso for, matar nunca", a etnografia dos índios, em seus vários desdobramentos científicos, amadores e visuais, era bastante sensível à necessidade de respeito ao índio como ser humano, sendo, ao mesmo tempo, completamente romântica. 
Podemos identificar a mesma ideia em Uoni-Uoni, por exemplo, quando Baldi retira das imagens as marcas da civilização, como as roupas de brancos usadas por índios. A própria criança como narradora da história também indica essa escolha. Em um nível, ela aproxima o narrador do seu público alvo infanto-juvenil. Em outro nível, sugere que o índio representava, em toda a sua riqueza cultural, a infância da humanidade.

É possível que fosse uma estratégia para mover os corações dos leitores na direção de uma atenção especial aos índios, e que dela

[...] resultasse um pouco de amizade, ou melhor compreensão dos leitores, para com os nossos irmãos de raça indígena, que como se sabe são os que têm mais direito, por assim dizer, a este território imenso, e que representam, cem por cento, o Brasil. (BALDI 1950: 6).

Representar o Brasil e ter direito ao território são atributos da antiguidade desses povos. Para realmente entendê-los, uma visita a sociedades afastadas dos brancos valia mais do que o encontro com índios em contato com os civilizados. É interessante notar que a construção dessas ideias está sempre ligada ao contexto de produção e veiculação das imagens. Podemos comparar duas que exemplificam esse argumento, uma foto feita por Baldi entre os índios Bororo em 1934-35 e uma ilustração sobre os mesmos índios feita pelo etnólogo alemão Erich Freundt. (Figuras 13 e 14).

Quando Herbert Baldus recomendou a Freundt uma visita à aldeia Bororo de Tóri-Páru, o fez pelo fato de que em 1935 eles ainda viviam em "independência" do contato com padres salesianos. Baldus registra o fato na apresentação do livro de Freundt, outro exemplar da indiologia da editora Melhoramentos (FREUNDT 1946). Freundt era excelente desenhista e optou por ilustrações ao invés de fotografias. Poderia, assim, subtrair e adicionar o que quisesse, aos modos de sua indiologia. 


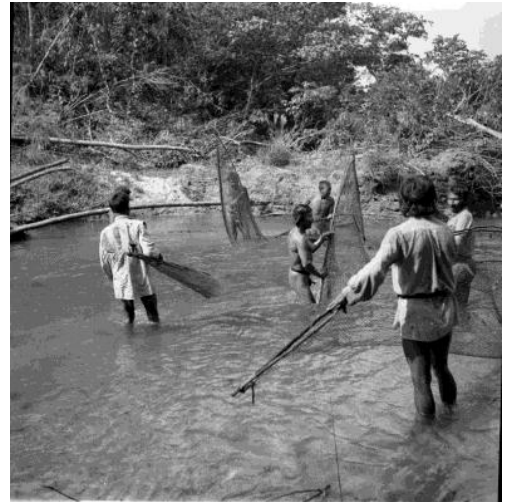

Figura 13: BALDI, Mario. "Bororós pescado". 1935. Neg.6x6. Baldi n³046. Weltmuseum Wien.

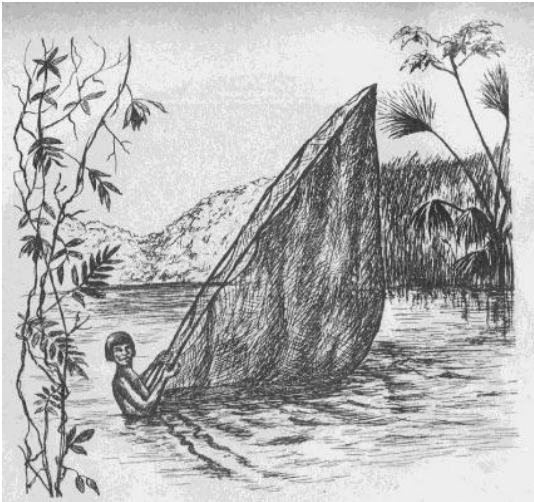

Figura 14: FREUNDT, Erich. "Poucos minutos distantes de Tóripáru desliza um córrego, em cujas águas os habitantes costumam banhar-se e pescar. A rede - buke na língua bororó - é estendida e amarrada em duas varas elásticas. Enquanto um homem remexe com um pau nas raízes submersas das árvores e nos buracos ribeirinhos, outro segura a rede aberta embaixo da água, procurando apanhar os peixes assustados.". In.: Índios de Mato Grosso. 10.

Havia uma perspectiva sugerida por Jean Levi-Strauss e Herbert Baldus, segundo a qual o etnólogo deveria buscar o índio mais tradicional possível. Porém, em diversas oportunidades, Mario Baldi fotografou costumes em transição, mudança cultural, e registrou visualmente a atividade descrita na legenda da imagem de Freundt, adicionando ainda as roupas de brancos que os Bororo usavam, pelo contato que já tinham com os "civilizados" nos anos 1930.

Já que o contato e a mudança não eram interessantes para Freundt, o registro fotográfico da pesca provavelmente não serviria à indiologia da qual Freundt participava. Aparentemente, foi isso que levou Baldi a subtrair exatamente as roupas dos índios nas imagens de Uoni-Uoni. Em 1935 andou no contrafluxo da antropologia, o que hoje tem a vantagem de registrar a situação cultural dos Bororo dos anos 1930. Já em seu livro, no contexto da indiologia, produziu uma visualidade romântica, adequada aos anos 1940-50, que hoje nos serve menos para entender os índios e mais para entender a indiologia como ideologia. 
Herbert Baldus tinha razão. A indiologia estava no centro de um conflito. Isso coloca Uoni-Uoni e as obras de autores contemporâneos que contribuíram nesse mesmo tom diante de uma questão complexa a ser resolvida: como conduzir o público letrado em direção ao Brasil, seu povo, sua formação e seu futuro.

De acordo com Renato Ortiz, os anos de 1930 e 1940 foram aqueles em que a intelectualidade brasileira tentou equacionar o problema da identidade nacional a partir da diversidade étnica e cultural que pluralizava a população do país. A questão era antiga: um território vasto e uma população dividida entre europeus, negros e indígenas. Ao final do século XIX, delineia-se entre a intelectualidade o pensamento do Brasilcadinho, ou seja, de um Brasil resultado do cruzamento das três raças. (ORTIZ 1985: 37).

Não obstante, a miscigenação racial era um entrave ao progresso, aos olhos de alguns autores oitocentistas como, por exemplo, o cientista suíço Louis Agassiz. Com o regime republicano e, principalmente, nos anos 1930, com a reorientação social e cultural promovida pelo Estado Novo (1937-1945), a miscigenação passa a ser considerada componente da identidade brasileira, muito em função da obra seminal de Gilberto FREYRE, Casa grande \& senzala, cuja idéia central era apreender o país a partir de pólos diversos e complementares. (ORTIZ 1985: 42).

O novo projeto de Brasil deveria investir na problemática dos contatos culturais e não na incompatibilidade racial. Como lidar com o inevitável choque oriundo de um Brasil urbano que almejava avançar sobre um Brasil incógnito? O cruzamento das raças poderia resolver a questão. (ORTIZ 1985: 92).

Particularmente expressiva é a longa reportagem fotográfica produzida por outro fotógrafo, Jean Manzon, e publicada na revista Paris Match, 14 anos depois da expedição de Mario Baldi. Metade de uma das páginas é dedicada à fotografia de legenda Rouge, blanc et noir. Na imagem, o homem branco domina o enquadramento, sendo o único que olha diretamente para a objetiva da câmera fotográfica, enquanto o negro e o índio complementam a cena e traduzem visualmente o título da reportagem: Brésil. (MANZON 1952).

Já Baldi destaca uma via de mão dupla, com imagens nas quais brancos e índios se destacam nos encontros entre culturas. O fotógrafo aproveitou as imagens de Doralice para construir essa ideia. Ele elevou a companheira de viagem a símbolo de brasilidade. Num primeiro olhar, pode-se dizer que isso confere superioridade absoluta 
à civilização do branco no discurso visual do fotógrafo. Porém, Doralice Avellar é, em si mesma, produto genuíno do Brasil, uma vez que é filha de pai escandinavo e mãe índia brasileira (BALDI 1950: 5). A variação baldiana do mito do cruzamento das raças faz com que o Brasil, simbolizado pela fotógrafa meio europeia meio índia, vá a busca de si mesmo, reconheça sua origem primeira, sua origem indígena. (Figuras 15 a 17)

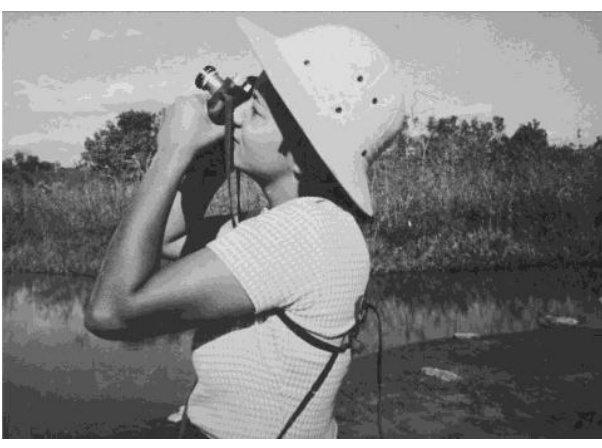

Figura 15: BALDI, Mario. Doralice Avellar, fotógrafa. Ilha do Bananal. 1938. Baldi $\mathrm{n}^{\circ} 4769$ S.M.C.T. Coleção Mario Baldi.

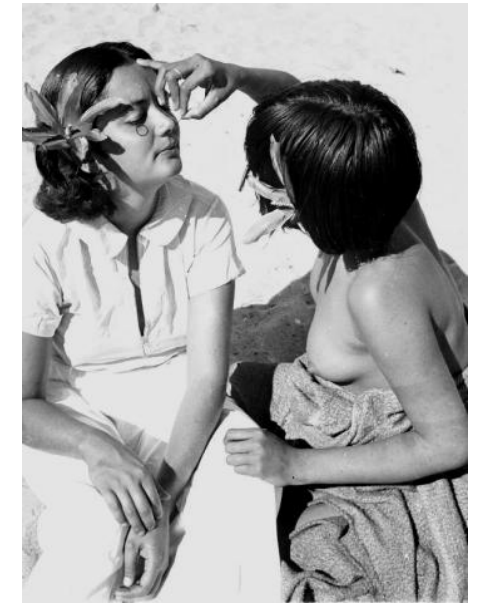

Figura 17: BALDI, Mario. Doralice deixa-se pintar com os desenhos da tribo e do clã. Ilha do Bananal, 1938. Baldi ${ }^{\circ}$ 5029 S.M.C.T. Coleção Mario Baldi.

Longe de ser uma questão resolvida para Baldi, a reflexão sobre o significado do Brasil bailava entre uma visão etnográfica do índio, a valorização de sua cultura como genuinamente brasileira e a ideia de que o avanço da civilização sobre o interior produziria o Brasil do futuro (cf. BALDI 1936). Considerando sua trajetória, percebe-se que a segunda metade dos anos 1930 e década de 1940 foi de reflexão sobre o problema do indígena e do projeto nacional que avançava sobre o Oeste brasileiro. $\mathrm{O}$ fim de seu vínculo empregatício com a imprensa carioca correspondeu ao início de uma nova fase, exatamente quando as fotografias dos Carajá, de 1936 e 1938, aparecem nas páginas de 
Uoni-Uoni conta sua história. A reinterpretação das fotografias recupera o tema dos encontros culturais e da necessidade de levar-se em conta a figura do índio na construção da identidade nacional.

As fotografias do livro de Mario Baldi normalmente aparecem como referência visual de algo que foi expresso verbalmente. As legendas das imagens, com exceção de poucas, são narradas pelo índio, em pleno acordo com o texto principal. Dentre as várias possibilidades abertas pelas imagens abundantes no livro, são particularmente expressivas aquelas que representam a alteridade cultural, estranhamento e descoberta, momentos em que diferentes culturas se encontram e tentam traduzir-se mutuamente.

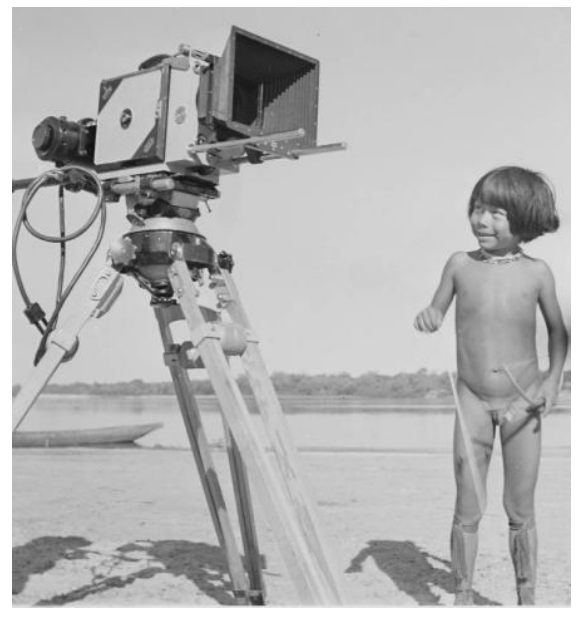

Figura 18: BALDI, Mario. "Caraja" / "Que coisa estranha!" / "Uoni-Uoni". Neg. $6 \times 6$ Baldi ${ }^{\circ}$ 4923. Folha-contato carajá 1938. Weltmuseum Wien.

Legenda do livro: "Eis o bicho esquisito de pernas de caranguejo gigante. Ele está zunindo que nem casa de marimbondo bravo. Mas meu irmão grande diz que são apenas as tripas do bicho que estão com fome", 79 .

Primeiramente, uma bela imagem em que se vê um pequeno índio contemplando a máquina filmadora (Figura 18). A direção do olhar do índio forma uma diagonal que se encontra com a direção da câmera, também um instrumento de olhar, e ambos são trazidos para o centro da fotografia, ainda que permaneça para o observador a distância e o estranhamento entre a máquina-expressão-da-cultura e o indiozinho-natureza. Por entre o tripé da câmera vê-se uma canoa dos carajá na beira do rio e, ao fundo, a mata. Com exceção da máquina, que, no entanto, domina a foto, todos os elementos da fotografia são indígenas: o índio em si mesmo, seu arco e flechas, a canoa e a paisagem que é seu habitat natural, para utilizar uma expressão comum à época. A construção da fotografia sugere certa pequenez do índio em relação à câmera, e sublinha a condição do novo e do estranhamento. O índio-narrador, explica o que o leitor vê, ao interpretar a máquina sem deixar de utilizar, como argumento de autoridade, as palavras do Tori, pois só mesmo o irmão grande fala a língua do "bicho" e pode explicá-lo. 
Eis o esquisito bicho de pernas de caranguejo gigante. Ele está zunindo que nem uma casa de marimbondo bravo. Mas meu irmão grande diz que são apenas as tripas do bicho que estão com fome. (BALDI 1950: 79).

O tema do estranhamento reaparece em uma imagem em que se invertem os papéis. Pela tomada, o índio em primeiro plano enche o centro do enquadramento e sua posição de destaque sugere, ao mesmo tempo, a pequenez do branco frente ao novo, estranho. Doralice Avellar, que recebe o nome de Behederu, é presenteada com uma flecha. $\mathrm{O}$ jogo de claro/escuro acentua o contraste entre os dois, sobretudo por estarem sobrepostos na imagem. (Figura 9).
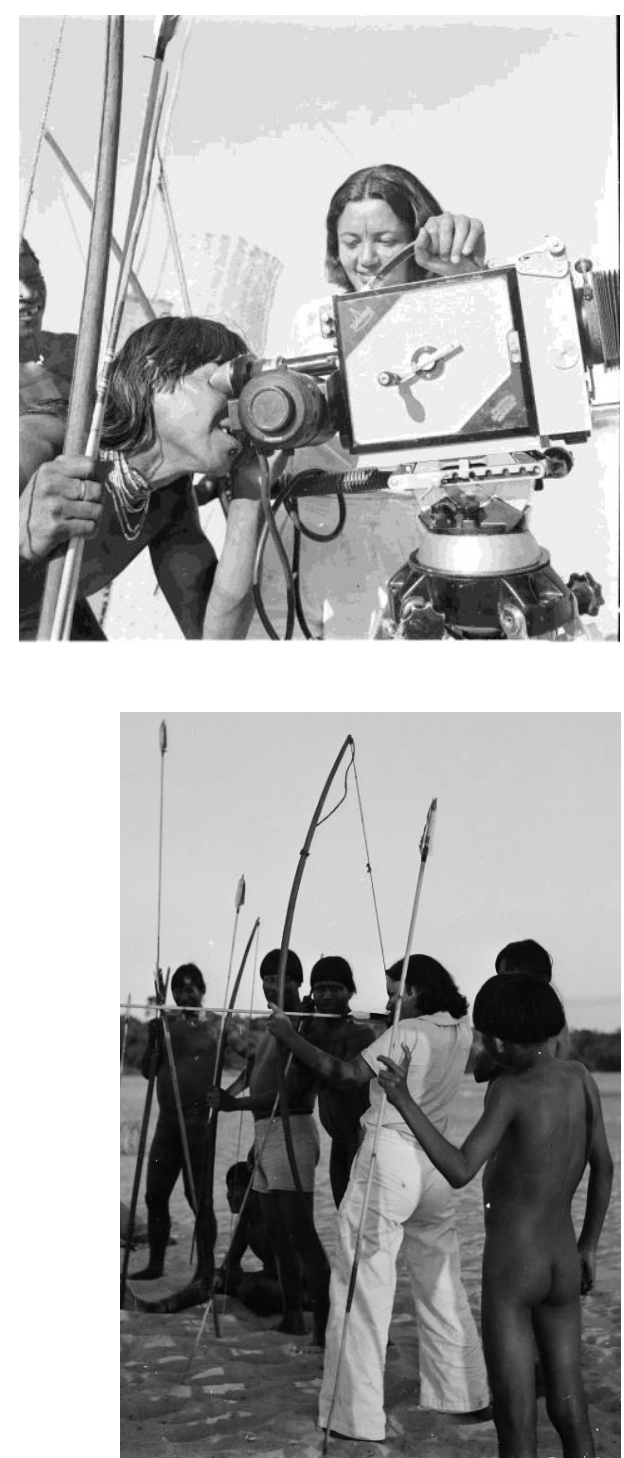

Figura 19: BALDI, Mario. "Carajá". Neg. 6x6 Baldi no 4921. Folha-contato Carajá 1938. Weltmuseum Wien. Legenda do livro: "Assim está bem, Kuhubara! Vês alguma coisa agora?”,77.
Figura 20: BALDI, Mario. Sem registro. 1938. Neg. 6x6 Baldi n4978. Folha-contato Carajá 1938 $n^{\circ} 12$ Coleção Mario Baldi, Weltmuseum Wien.

Legenda do livro: "Uoni-Uoni mexe nervosamente os dedos porque Behederu está segurando errado a flecha", 69.

O contato entre culturas, que se inicia no reino do estranhamento, passa, nas imagens, para o campo da experimentação. É nesse sentido que a alteridade toma contornos de 
interação, uma preocupação do autor, como nas imagens que seguem. Nelas, vemos o branco e o índio, cada um ao seu modo, ensinando algo ao outro. Agora, aquilo que antes era estranho, passa ser o ponto de contato entre as culturas, as ferramentas do branco e do índio.

A cinegrafista leva o pajé Kuhubara a olhar através da câmera (Figura 19). De início o pajé não vê coisa alguma. "Cerra bem os olhos e bem perto do tubo. Assim, está bem! Vês alguma coisa agora?” (BALDI 1950: 76). O desconhecimento dos códigos, que, no caso, leva à dificuldade de ver algo através da objetiva da câmera, não é um problema exclusivo do índio. Ele é sugerido por outra passagem e imagem em que Behederu toma aulas de arco e flecha (Figura 20). Na fotografia vemos seis índios e, em meio a eles, a moça que surpreendeu a aldeia por estar "metida em calças compridas".

Novamente sua roupa branca faz contraste com os corpos indígenas, e acentua a diferença. A legenda, outra vez, joga com a distância cultural entre branco e índio, já que, enquanto o pajé não sabe como olhar pela câmera, Behederu também não tem conhecimento "das coisas da selva”, para usar uma expressão de Baldi em algumas passagens do livro. Mas o afastamento de costumes e culturas é representado pela interação dos homens e mulheres que as representam.

É possível sugerir que a alteridade cultural será definida, no livro em questão, segundo as práticas e trajetórias do escritor e fotógrafo que é o autor. No caso fotográfico, foco, distância e enquadramento podem ser elementos que definem o afastamento cultural entre fotógrafo e fotografado, tal como sugeriram MACINTYRE e MACKENZIE (1992). Ainda segundo essas autoras, devem-se questionar a tipicalidade e a representatividade do fotógrafo, se considerado na série de outros fotógrafos e imagens, ou, se ampliarmos o raciocínio, a particularidade do escritor no conjunto de outros autores e textos. Mario Baldi está entre os poucos fotógrafos que se dedicaram à escrita sistemática. E, se seu gesto autoral deve ser analisado, é preciso considerar sua representatividade, ao ter em vista sua prática especial.

A argumentação não quer sugerir um olhar romântico sobre o pensamento de Mario Baldi, livre de preconceitos e hierarquizações raciais típicas de seu tempo. A escolha do índio como narrador de sua própria história, por mais peculiar que possa ter sido, não significa uma abordagem pura e objetiva sobre a questão indígena no Brasil. O autor não consegue resolver o problema do choque de culturas, as diferenças existentes 
entre os protagonistas da narrativa saltam das páginas e chegam ao leitor, ele mesmo um Outro em relação ao narrador, que é um índio fictício.

A confissão de Baldi no prefácio ao livro, quando registra seu desejo por amizade entre brancos e índios, reflete certa incerteza e expectativa de uma resolução posterior ao problema, ainda não encontrada pelo projeto nacional. A raça indígena é raça irmã e, no entanto, é a única que representa genuinamente o Brasil. Os índios têm direito a terra, mas o que dizer da fórmula "as nossas selvas e seus filhos", (BALDI 1950: 6) constantemente utilizada por Baldi e outros para designar o "sertão" e os indígenas?

Os índios Carajá, na fotografia de Mario Baldi, foram representados na construção de uma visão de Brasil específica, datada da primeira metade do século XX, na qual o mito do cruzamento das raças foi elevado ao patamar de substância da identidade nacional. Não obstante, a equação que se resolvia ao nível do discurso não escondia totalmente os choques étnicos e culturais que emergiam do avanço do Brasil urbano sobre o Brasil "incógnito". As fotografias desses índios, produzidas em 1938 e que refiguram no livro de Baldi, não só são frutos do período no qual foram produzidas e publicadas, mas também compõem a interpretação dada pelo fotógrafo ao complexo processo de convivência, conflito e negociação entre as sociedades indígenas e os demais grupos sociais brasileiros.

Finalizando, é preciso mencionar que Baldi não se limitou a usar a experiência com Doralice e os Carajá para pensar a formação do povo brasileiro. A sugestão do Dr. C.E., para que Baldi continuasse sua história sobre Uoni-Uoni, era também compartilhada pelo fotógrafo:

Ich möchte nun im Juli oder September zu den Kalapaloinios [Kalapaloindios] am Rio Culuene fliegen, wo der englische coron. P. Fawcet damals (1925) verschwunden ist. Ich war bei dem Stamm schon einmal (1946/47) und aber keine Expedition machen. Nur dort im Dorf 2-4 Wochen bleiben und nimm mir einen 14 jährigen weissen und einen neger jungen mit und 1 [ich?] lasse diese mit einem gleichaltrigen Indio jungen dort allerhand „Erlebnisse erleben“ und mache die Fotos dazu. Das alles ist Material für ein neues Jugenbuch das ich in dieser Form schreib von drei Jungens aus den drei Rassen, aus denen die Brasilian. Nation besteht (Weisse/Indios/Neger). Ich hoffe, es klapt alles! (BALDI 1953, s/p.).

Como no caso das narrativas em A Noite illustrada, novamente a aldeia é um palco para uma encenação. Como Baldi não concluiu esse projeto, nunca poderemos avaliar os resultados. Mas a descrição que fez aponta para uma nova versão do velho Brasil- 
cadinho que se desenrola numa terra misteriosa, onde coronéis experimentados como Fawcet desaparecem numa selva de índios.

Como essência do povo brasileiro, as fotos da miscigenação seriam ícones de apelo social e cultural para os leitores. Como argumentaram acertadamente John LUCAITES e Robert HARIMAN, as foto-ícones tem íntima relação com a performance de saberes sociais difundidos e aceitos (cf. HARIMAN/ LUCAITES 2007). Aproprio-me da ideia e a adapto para o caso de Mairo Baldi. Os autores chamam a atenção para o fato de que a fotografia se distanciaria da performance, pois depende da reprodução mecânica e performance se dá uma vez e é um acontecimento efêmero. Porém, afirmam os autores, toda performance é "restored" e " "twice-behaved' behavior" (HARIMAN/ LUCAITES 2007: 32). É uma ideia equivalente à expressão que Baldi usa para definir o papel de seus atores: "Erlebnisse erleben", ou seja, "vivenciar vivências". A ideia era proporcionar as condições para observar e fotografar a formação do Brasil pelas três raças. No pensamento do fotógrafo, a mistura racial era uma verdade na qual residia a essência nacional e, por isso, sua encenação seria legítima: seus atores estariam apenas reproduzindo o que se dá na vida real.

Para ser socialmente inteligível, a performance ou, em nosso caso, a fotografia, trabalha com imitações de atividades que ocorrem repetidamente na sociedade. A repetitividade de qualquer fotografia é uma representação icônica do objeto que é visto dentro de suas molduras:

Thus, the photograph is capable of providing deep knowledge of social reality, both in its specific manifestations and as it is itself an unending process of repetition... iconic photographs are aesthetically marked, situated, reflexive examples of 'restored behavior' presented to an audience. Through phenomenological devices such as framing, the iconic image highlights the deeply repetitive features of social life, a condition reinforced further by the mechanical reproduction of the photograph itself. (HARIMAN/ LUCAITES 2007: 32).

Assim, a imagem estrutura a compreensão, motiva ações e organiza a memória coletiva. A performance cívica estudada pelos autores norte-americanos pode ser adaptada para uma performance nacional das raças, no caso da representação do povo brasileiro. Ela refletiria, nas fotografias, a relação do indivíduo leitor - que se vê na imagem - com o coletivo do qual faz parte. Por fim, devemos registrar que a intenção de Baldi de levar um branco e um negro até ao encontro do índio, para a encenação de uma experiência 
Lopes, M. B. - Indiologia brasileira

real e secular, torna a considerar o índio e seu espaço de vivência como um lugar original, onde teria se iniciado a trajetória do Brasil.

\section{Referências bibliográficas}

BALDI. Mario. Carta a Anna Baldi, 27 de março de 1953. Arquivo privado da família Weinkamer, Salzburg, Áustria.

BALDI. Mario. Uoni-Uoni conta sua história. São Paulo, Melhoramentos, 1950.

BALDI. Mario. Uoni-Uoni oder die letzten Indianer am Großen Wasser. Düsseldorf, BastionVerlag, 1952.

BALDUS, Herbert. Apresentação. In: FERREIRA, Manoel Rodrigues. Cenas da Vida Indígena. São Paulo, Melhoramentos, 1951.

BEGER, John. Pig earth. New York, Vintage International, 1992.

C.E., DR. "Büchermarkt". Deutschen Wochenblatt, 14/2/1953. Coleção Mario Baldi. SMCT. MB-P-PC-C $3 / 079$

CHIAPPINI, Ligia. O índio na literatura brasileira: de personagem a narrador e autor. In: RoSA, Caetano da, SchÖNBERGER, Axel e ScOTTI-Rosin, Michael. (Orgs.) Lusorama, Zeitschrift für Lusitanistik/Revista de Estudos sobre os Países de Língua Portuguesa. (N. 61/62), Frankfurt am Main, TFM, 2005: 29-62.

ClIFFORD, James. A experiência etnográfica: antropologia e literatura no século XX. Organização de José Reginaldo Santos Gonçalves. Rio de Janeiro, UFRJ, 1998.

Costa, Angyone. Indiologia. Rio de Janeiro, Biblioteca Militar, Ministério da Guerra, 1943.

FERrEIRA, Manoel Rodrigues. Cenas da vida indígena. Rio de Janeiro, Melhoramentos, 1951.

FREUNDT, Erich. Índios de Mato Grosso. Rio de Janeiro: Melhoramentos, 1946.

HARIMAN, Robert and LUCAITES, John Louis. No caption needed. Iconic photographs, public culture and liberal democracy. Chicago: University of Chicago Press, 2007.

LÉvi-STRAuss, Claude. Tristes Trópicos. São Paulo, Companhia das Letras, 1996.

MACINTYRE, Martha e MACKENZIE, Maureen. Focal lenth as analogue of cutural distance. In: EDWARDS, Elizabeth. (Ed.) Antropology and Photography - (1860-1920). New Haven/London, Yale University Press, 1992.

MAnzon, Jean. "Brésil". In: Paris Match. (147). 12/1/1952. S.M.C.T. Coleção Mario Baldi, MB-P-A.

Melhoramentos, Catálogo da editora. Coleção Mario Baldi. S.M.C.T. MB-P-PC-C3/080

MitChELl, W.J.T. There are no visual media. In: Journal of Visual Culture, 4(2): 257-266. London, Thousand Oaks, CA and New Delhi: SAGE Publications 2005.

ORTIZ, Renato. Cultura Brasileira e identidade nacional. São Paulo, Editora Brasiliense. 1985.

REVISTA DA SEMANA. "Fora do Prelo". 1952.

REVISTA DA SEMANA. "Semana Literária - Fora do Prelo". s/d

RICOUER, Paul. Tempo e Narrativa - Tomo III. 2a . Ed. São Paulo, Papirus Editora, 1997.

SCHLOss, Carol. In visible light. Photography and the american writer. New York \& Oxford, Oxford University Press, 1987. 